\title{
Possible Association Between the Chemokine Receptor Gene CCR5- Delta32 Mutation and Hepatitis C Virus Pathogenesis
}

\author{
*Kouka Saad Eldin Abdel-Wahab, **Mohamed Foda, *Magda Abdel- \\ Moneim Gamil, *Azza-Hassan El-salakawy, ***Gamal El-Attar, \\ **Shinji Harada, **Yosuke Maeda \\ *Department of Medical Microbiology, Faculty of Medicine for Girls, \\ Al-Azhar University; Cairo, Egypt; **Department of Medical Virology School of \\ Medicine, Kumamoto University, Japan; ***Department of Internal Medicine, \\ Theodore Bilharz Institute, Imbaba, Egypt
}

\begin{abstract}
Background: CCR5-Delta32, a 32-base pair deletion of the CC chemokine receptor (CCR)5 gene, is associated with slowed human immunodeficiency virus disease progression in heterozygotes and protection against infection in homozygotes between carriers and non-carriers of each genetic variant. The present study investigated the frequency and clinical consequence of the CCR\%-Delta32 mutation in Egyptian HCV infected patients. Genomic DNA samples from 150 patients with chronic HCV infection were screened by PCR for the presence of the CCR5-Delta32 polymorphism. One hundred blood donors were used as control population.

Results: The frequency of CCR5-Delta32 heterozygosity was $0.67 \%$ in chronic hepatitis C virus and $0 \%$ in controls. The CCR5-Delta32 allele was not associated with any of the clinical parameters of hepatitis $\mathrm{C}$ virus infection.

Conclusion: In this study, the frequency of CCR5-Delta32 homozygosity in patients with hepatitis $\mathrm{C}$ was similar to controls.
\end{abstract}

\section{Introductio}

Chemokine and chemokine receptor genes are strong candidate genes for outcome of HCV. Chemokines are 8- to 10kd proteins with $20 \%$ to $70 \%$ homology in amino acid sequences. There are approximately 40 chemokines identified to date, which are classified according to the configuration of cysteine residues near the $\mathrm{N}$ terminus into 4 families: CC-, CXC-, and CX3C-. They play important roles in leukocyte trafficking to sites of infection and in regulating $\mathrm{T}$ helper cell polarization. They also have crucial roles in linking innate and adaptive immunity. Chemokine receptors are G-protein coupled, 7-transmembrane receptors, which are categorized based on the chemokine class they bind. Chemokine-chemokine receptor interactions are likely to be important in chronic hepatitis $\mathrm{C}$, where $\mathrm{T}$ cells are recruited to the liver parenchyma to mediate clearance of HCV-infected hepatocytes. Several allelic variants of chemokine receptors have been shown to be important in the pathogenesis of viral infection. The most widely known, a 32-base-pair deletion in the open reading frame of CCR5 (CCR5D32) is associated with protection against human immunodeficiency virus 1 (HIV-1) infection and delayed progression to AIDS in white populations.

The importance of the HIV-1 coreceptors has been highlighted by the fact that individuals who possess two alleles of a 32-base pair deletion in CCR5 coreceptor gene that abrogates cell surface expression of the CCR5 molecule display near absolute resistance to HIV-1 transmission (Dean et al., 1996). About $20 \%$ and $1 \%$ of Caucasians are heterozygous and homozygous, respectively, for the CCR5-Delta 32 allele (Huang et al., 1994). 
Around $15-20 \%$ of the general population of Egypt are seropositive by ELISA for antibodies against HCV (Frank et al., 2000). Reasons behind this prevalence are still unresolved. A very high prevalence of 58 antibody against hepatitis $\mathrm{C}$ virus $(\mathrm{HCV})$, a marker of HCV infection, indicated a high morbidity and mortality from HCV induced chronic liver disease, cirrhosis, and hepatocellular carcinoma (Arthur et al., 1997). Hepatitis C virus (HCV) infection results in chronic hepatitis in more than $80 \%$ of infected patients while $10-20 \%$ of patients recover spontaneously. Host genetic factors may influence the ability to clear the virus after infection.

The importance of the chemokine system in the pathogenesis of $\mathrm{HCV}$ has been the main focus of several recent epidemiologic studies (Woitas et al., 2001, 2002). Woitas et al. (2001, 2002) showed a higher incidence of $\mathrm{HCV}$ infection among CCR5-Delta 32/Delta 32 homozygotes and 32-base pair deletion is positively correlating with $\mathrm{HCV}$ severity progression. However, other studies showed no relation between Delta-32 mutation and frequency of HCV infection (Lichterfeld et al., 2002; Glass et al., 2004; Ruiz-Ferrer et al., 2004). In this study we aimed to find out the possible correlation between CCR5-Delta 32 allele and $\mathrm{HCV}$ pathogenesis among $\mathrm{HCV}$ infected Egyptian patients.

\section{Material and Methods \\ Study Subjects}

The subjects were 100 apparently healthy blood donors (all are males; age range 18-43 years) were randomly selected as a reference group and 150 anti-HCV positive chronic HCV patients (82 males 68 females; age range 27-75 years). None of these patients had received interferon therapy at the time of the study.

\section{Sample Collection:}

Blood samples were drawn in EDTAtreated tubes, and peripheral blood mononuclear cells (PBMC) were prepared by ficoll-density gradient separation immediately after phlebotomy. The cells were washed in phosphate buffered saline (PBS) and pelleted for immediate DNA extraction or stored at $30^{\circ} \mathrm{C}$ until analysis.

\section{Genotyping of the CCR5 $\Delta$ polymorphism by polymerase chain reaction:}

Genomic DNA was extracted from PBM using the QIA amp Blood Mini Kit (Qiaga) according to the manufacturer's protocol. The CCR5-32 gene polymorphism was analyzed by PCR on a thermal Cycler (Biometra) by using DNA from PBMC for the presence or absence of the CCR5-Delta 32 deletion by using allele-specific PCR amplification. Detection steps were done as mentioned by Yudin et al. (1998) including design of the primer set for CCR5. The primer set CCR5F (5'-GAAGGTCTTCATTACAC CTG-3') and CCR5R (5'AGAATTCCTGGAAGGTGT-TC-3'); was used to amplify a 276-bp fragment. Thermal profile was: $\left(95^{\circ} \mathrm{C}\right.$ for $1 \mathrm{~min}, 56^{\circ} \mathrm{C}$ for $1 \mathrm{~min}$, and $73^{\circ} \mathrm{C}$ for $1 \mathrm{~min}$ ), and DNA was amplified for 30 cycles. The PCR products were analyzed in $2 \%$ agarose gel and stained with ethidium bromide.

\section{Results}

Using allele-specific PCR the CCR5-Delta 32 deletion was not detected in a significant percentage in chronic HCV (Table 1) or in the controls.

Table (1): Assay of the CCR5 Delta 32 allele in Egyptian blood donors and chronic hepatitis $\mathrm{C}$ virus patients

\begin{tabular}{|l|l|l|l|l|}
\hline \multirow{2}{*}{ Subjects } & \multirow{2}{*}{ No. } & \multicolumn{3}{|c|}{ CCR5 Genotype } \\
\cline { 3 - 5 } & & $\begin{array}{l}\text { CCR5/CCR5 } \\
\mathrm{n}(\%)\end{array}$ & $\begin{array}{l}\text { CCR5/ } \\
\mathrm{n}(\%)\end{array}$ & $\begin{array}{l}\Delta 32 / \Delta 32 \\
\mathrm{n}(\%)\end{array}$ \\
\hline Blood donors & 100 & $100(100 \%)$ & $0(0)$ & $0(0)$ \\
\hline Anti-HCV positive patients & 150 & $149(99.3 \%)$ & $1(0.67 \%)$ & $0(0)$ \\
\hline
\end{tabular}




\section{Discussion:}

Ruiz-Ferrer et al. (2004) have detected the CCR5-Delta 32 allele in 15 of $278 \mathrm{HCV}$ patients chromosomes $(5.4 \%)$ and 15 of 200 control chromosomes $(7.5 \%)$. The CCR2V64I allele was present in 24 of $278 \mathrm{HCV}$ chromosomes $(8.6 \%)$ and 19 of 200 control chromosomes $(9.5 \%)$. Analysis of the histological parameters showed no statistical significance when comparing the patients carrying the variants vs. the cases with the wild-type allele. They concluded that the CCR5-Delta 32 and CCR2-V64I polymorphisms are not related to the response to $\mathrm{HCV}$ infection, histological damage and outcome of infection in cohort of Spanish HCV patients. Lichterfeld et al. (2002) was analyzed inpatients with chronic hepatitis C and hepatitis B infection and compared with healthy subjects. Although CCR4 surface expression was not altered, hepatitis $\mathrm{C}$ virus (HCV)-infected patients had lower proportions of CD8 T cells with CCR1 and CCR5 surface expression ( $\mathrm{P}<$ 0.05). Migration of CD8 T cells in response to MIP-1 alpha, MIP-1 beta, and RANTES was significantly reduced in $\mathrm{HCV}$-infected patients $(\mathrm{P}<0.05)$. Intracellular CCR1 and CCR5 protein and messenger RNA levels in peripheral blood $\mathrm{T}$ cells did not indicate reduced chemokine receptor biosynthesis in hepatitis $\mathrm{C}$ infection. Thus, they concluded that chronic hepatitis $\mathrm{C}$, but not hepatitis $\mathrm{B}$, infection alters surface expression of distinct CCRs, resulting in lower CC chemokine responsiveness.

Konishi et al. (2004) studied the influence of CCR5 promoter polymorphism on the interferon response of Japanese patients with chronic hepatitis C. In a cohort of 105 patients with chronic hepatitis $\mathrm{C}$ as well as in 50 sustained responders and 55 non-responders the presence of polymorphisms such as CCR5-Delta 32, CCR 559029G/A, CCR 2 V641 and RANTES -403 G/C was determined. Gender, age, liver histological staging, pretreatment ALT levels, total dose of IFN and frequencies of polymorphisms (CCR2 V641 and RANTES - $403 \mathrm{G} / \mathrm{C}$ ) did not significantly differ between the two groups.
A low viral load, hepatitis $\mathrm{C}$ virus (HCV) serotype 2 and CCR 559029 G/G were significantly associated with a higher probability of a sustained response ( $\mathrm{p}<$ $0.01, \mathrm{P}<0.05, \mathrm{p}<0.05$, respectively). Multiple logistic regression analysis showed that a low viral load, HCV serotype 2 and CCR5 59029 G/G were independently associated with a sustained response [odds ratio 3.980 (1.647-9.621), $\mathrm{p}$ $=0.002 ; 3.584(1.439-8.924), \mathrm{p}=0.006$; $3.638(1.163-11.379), \mathrm{p}=0.026$, respectively]. These findings indicated that CCR5 59029 is a host genetic factor that is associated with responses to IFN therapy among Japanese patients with chronic hepatitis C. Glas and Colleagues (2004) found that the Delta 32 mutation was not observed in an increased frequency in HCV infections. Furthermore, a significant difference of the HCV load or aminotransferase concentrations was not observed in carriers versus non-carriers of the Delta 32 mutation. After stratification for potentially confounding factors such as gender or $\mathrm{HCV}$ genotype, a significant difference was also not detected with respect to treatment outcome. These observations argue strongly against a role of CCR5 for susceptibility to $\mathrm{HCV}$ infection or response to combination therapy. Response rates to interferon-alpha mono-therapy are reduced in hepatitis $\mathrm{C}$ virus (HCV) infected patients carrying the CCR5-Delta 32 mutation. However, interferon/ribavirin combination treatment may overcome this negative effect of CCR5-Delta 32 (Ahlenstiel et al., 2003). Hellier et al., (2003) found significant associations between CCR-Delta 32 and reduced portal inflammation and milder fibrosis. A promoter polymorphism at position -403 in the RANTES gene was associated with less severe portal inflammation. An amino acid change in MCP2, Q46K, was associated with severity of fibrosis.

Our results indicated that CCR5-delta 32 allele mutation is not related to chronic $\mathrm{HCV}$ infection of the Egyptian patients investigated in this study. 


\section{References}

1. Ahlenstiel G, Berg T, Woites RP, Grunhage F, Iwan A, Hess L, Brackmann HH, Kupfer B, Schernick A, Sauerbruch T, Spengler U (2003). Effects of the CCR5-Delta 32 mutation on antiviral treatment in chronic hepatitis C. J Hepatol. 39:245-252.

2. Dean $\mathbf{M}$, Carrington $\mathbf{M}$, Winkler $\mathbf{C}$, Huttley GA, Smith MW, Allikmets R, Goedert JJ, Buchbinder SP, Vittinghoff E, Gomperts E, Donfield S, Vlahov D, Kaslow R, Saah A, Rinaldo C, Detels R, O'Brien SJ (1996). Genetic restriction of HIV-1 infection and progression to AIDS by a deletion allele of the CKR5 structural gene. Hemophilia Growth and Development Study. Multicenter AIDS Cohort Study, Multicenter Hemophilia Cohort Study, San Francisco City Cohort, Chicago IL USA. ALIVE Study. Science. 273: 1856-1862.

3. Glas J, Torok HP, Simperl C, Konig A, Martin K, Schmidt F, Schaefer M, Scheimann U, Folwaczny C (2004). The Delta 32 mutation of the chemokinereceptor 5 gene neither is correlated with chronic hepatitis $\mathrm{C}$ nor does it predict response to therapy with interferon-alpha and ribavirin. Clin Immunol. 108:46-50.

4. Hellier S, Frodsham AJ, Hennig BJ, Klenerman P, Knapp S, Ramaley P, Satsangi J, Wright M, Zhang L, Thomas HC, Thursz M, Hill AV (2003). Association of genetic variants of the chemokine receptor CCR5 and its ligand, RANTES and MCP-2, with outcome of HCV infection Hepatology 38: 1468-76.

5. Joint United Nations Programme on HIV/AIDS and World Health
Organization (2002). AIDS Epidemic Update: UNAIDS, Durban.

6. Konishi I, Horiike N, Hiasa Y, Michitaka K, Onji M (2004). CCR5 promoter polymorphism influences the interferon response of patients with chronic hepatitis C in Japan. Intervirology, 47: 114-120.

7. Lichterfeld M, Leifeld L, Nischalke HD, Rockstroh JK, Hess L, Sauerbruch T, Spengler U (2002). Reduced CC chemokine receptor CCR1 and CCR5 surface expression on peripheral blood $\mathrm{T}$ lymphocytes from patients with chronic hepatitis C infection. J Infect Dis. 185: 1803-1807.

8. Ruiz-Ferrer M, Barroso N, Alntinolo G, Aguilar-Reina J (2004). Analysis of CCR5-Delta 32 and CCR2-V641 polymorphisms in a cohort of Spanish HCV patients using real-time polymerase chain reaction and fluorescence resonance energy transfer technologies. J Viral Hepat. 11: 319-323.

9. Woitas RA (2001). $8^{\text {th }}$ Conference on Retroviruses and Opportunistic Infections. Chicago IL USA.

10. Woites RP, Ahlenstiel G, Iwan A, Rockstroh JK,Brackmann HH, Kupfer B, Matz B, Offergeld R, Sauerbruch T, Spengler U (2002). Frequency of the HIVprotective CC chemokine receptor 5$\Delta 32 / \Delta 32$ genotype is increased in hepatitis C. Gastroenterology, 122:1721-1728.

11. Yudin NS, Vinogradov SV, Potapova TA, Nakova TM, Sitnikova VV, Kulikov IV, Khasnulin VI, Knochuk C, Vloschinskii PE, Ivanov SV, Kobzev VF, Romaschenko AG, Voeda MI (1998). Distribution of CCR5-Delta 32 gene deletion across the Russian part of Eurasia. Hum Genetics 102: 695-698. 


\section{CCR5- ) المال تواجد ارتباط بين تطقر المستقبل الجيني كيموكين} Delta32

*ـ كوكا سعد الدين عبد الوهاب ، **ــ محمد بهاء الدين فودة ، *ـ ماجدة عبد المنعم جمبيل

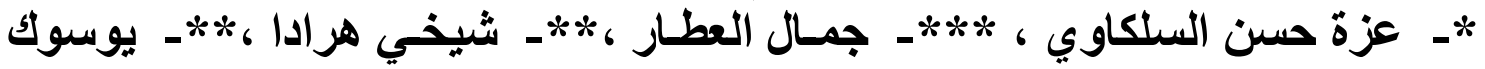

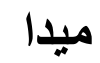

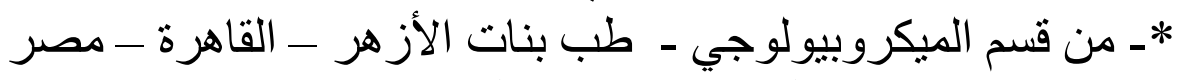

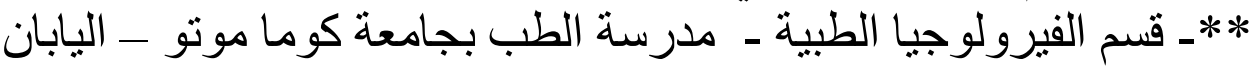

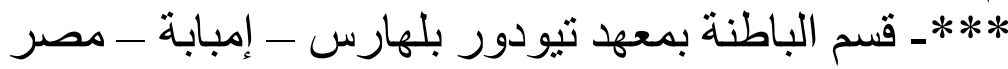

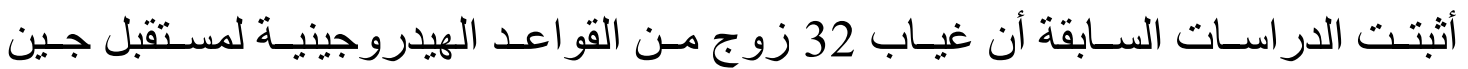

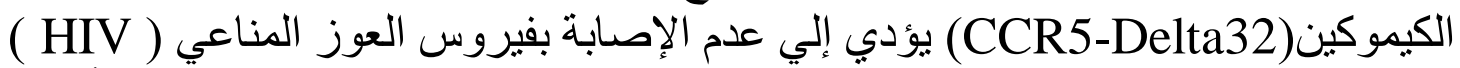

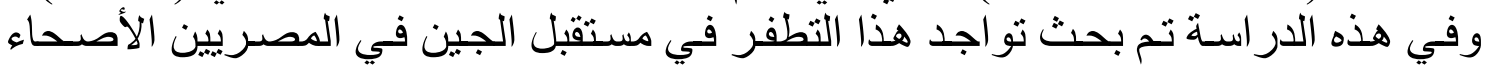

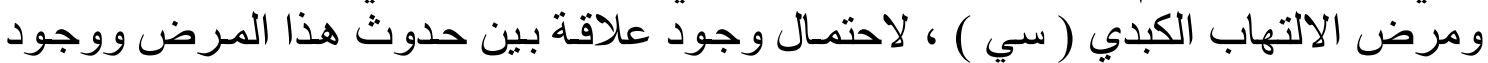

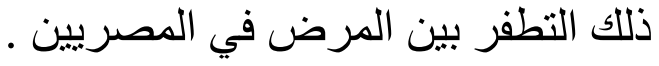

وقد أخذت 150 عينة من الدنا الجيني من مرض الالتهاب الكبدي المزمن ( سي ) ، 100

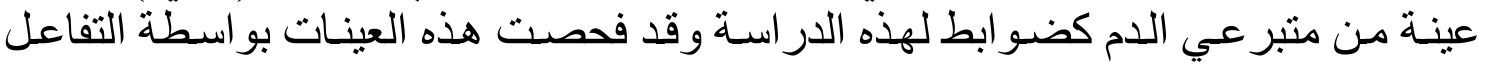

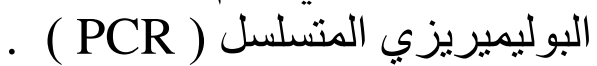

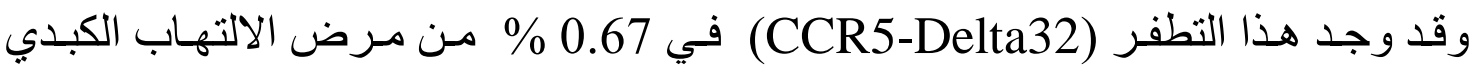

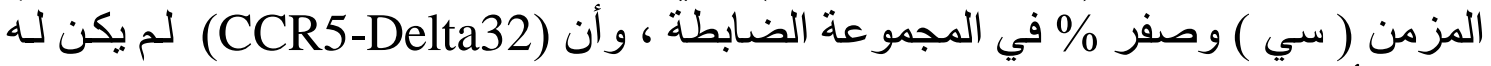

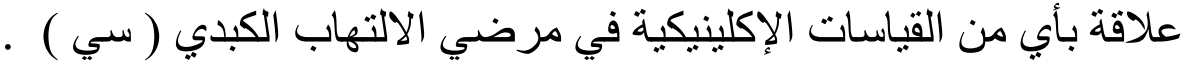

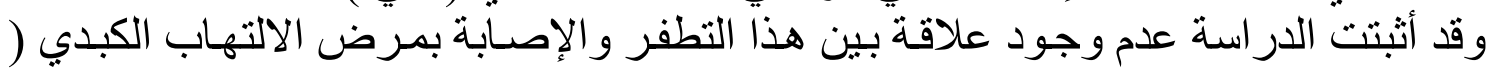

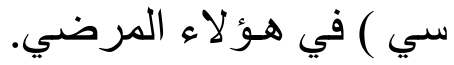

